\title{
XEOL STUDIES OF IMPURITY CORE-VALENCE LUMINESCENCE IN MIXED RUBIDIUM CAESIUM CHLORIDE CRYSTALS
}

\author{
V. B. Mikhailik \\ Physics Department, University of Oxford \\ Keble Road, Oxford OX1 3RH, UK
}

(Received January 24, 2005)

\begin{abstract}
The impurity core valence luminescence $(\mathrm{CVL})$ of $\mathrm{Rb}_{0.82} \mathrm{Cs}_{0.18} \mathrm{Cl}$ mixed crystals was monitored at the $\mathrm{Cl} \mathrm{K}$ - and $\mathrm{Rb} \mathrm{L}_{3}$-absorption edges using X-ray excited optical luminescence (XEOL) technique. It is found that XEOL spectrum at the chlorine K-edge is identical with the Cl K-absorption spectrum of pure RbCl. It is demonstrated that investigation of the XEOL yield spectra of impurity CVL can deliver essential site sensitive information about the structure of the CVL emission centre.

Key words: $\mathrm{Rb}_{1-x} \mathrm{Cs}_{x} \mathrm{Cl}$, impurity core-valence luminescence, XEOL.

PACS number(s): 78.55.-m, 78.55.Hx, 78.55.Fv, 71.51.-y
\end{abstract}

\section{INTRODUCTION}

X-ray absorption spectroscopy is known to be a powerful tool in studies of the electronic and structural properties of crystals. X-ray absorption near edge structure (XANES) usually is measured as a total electron yield or X-ray fluorescence yield [1]. Measurement of the optical luminescence caused by X-ray excitation of deep core levels can be considered as a complementary method for detecting XANES [2-4]. Studies of the optical response of the materials across the X-ray absorption edge are of considerable interest since they provide the testing ground for the notion on site selectivity of the XEOL technique [5]. Thus, examination of the materials with the simple structure is thought to be especially helpful in getting insight into this issue.

Recently a new type of the optical emission has been explored in Cs-doped chlorides under high-energy excitation $[6-8]$. The luminescence results from radiative recombination of the holes originating from the shallowlying impurity core states and valence electrons that gives it the obvious name - impurity core-valence luminescence (CVL). The emission has a number of specific characteristics, i. e., high thermal stability, fast decay time $\left(\sim 10^{-9} \mathrm{~s}\right)$, excitation threshold which is controlled by the energy position of the impurity core state. Bearing in mind these features I believe that there is a sound reason to investigate the material with impurity $\mathrm{CVL}$ using XEOL technique. This study can shed light upon the assignment of the XANES. It can also give a better understanding of the nature of luminescence. Motivated by this idea I initiated an experiment aimed to measure the excitation spectra of impurity CVL in mixed rubidium-caesium chloride crystals using monochromatic $\mathrm{X}$-ray photons provided by synchrotron radiation source. This is the first examination of the material with the impurity CVL in the region of deeply core shells.

\section{EXPERIMENTAL}

The $\mathrm{Rb}_{0.18} \mathrm{Cs}_{0.82} \mathrm{Cl}$ mixed crystal investigated in this study was grown using modified Bridgman technique as described in [8]. The luminescence measurements were carried out at the 4.2 beamline of the SRS Daresbury laboratory using the mobile luminescence end-station MoLES [9]. The beamline is equipped with double crystal InSb monochromator that covers the range of energies from 2 to $4 \mathrm{keV}$ providing the photon flux $\sim 10^{11}$ photons/sec and resolution $1 \mathrm{eV}$ at $\mathrm{S}$ K-edge $(2472 \mathrm{eV})$. The samples where mounted in the holder of a closed-cycle cryostat, allowing measurement of luminescence spectra over the temperature range 8-295 K using a Triax190 Jobin-Yvon monochromator (resolution $7 \mathrm{~nm}$ ) and a GaAs Hamamatsu R2949 photomultiplier. Given that the emission band of interest is located in the UV range (maximum at $280 \mathrm{~nm}$ ) to enhance the sensitivity of detection system the excitation spectra were measured in integrated regime through the band-pass UV filter UG5 (3 mm, maximum transmittance at $320 \mathrm{~nm}$ ) using a bialkali Electron Tubes 9111WB photomultiplier. The flux of the incident radiation was monitored by measuring the drain current signal from an aluminium foil. The luminescence spectra presented here are corrected for the dispersion (square-of-lambda correction) and the instrumental response of the detection system.

\section{RESULTS AND DISCUSSION}

Under excitation with the high-energy photons the impurity CVL spectrum of lightly-doped $\mathrm{Rb}_{1-x} \mathrm{Cs}_{x} \mathrm{Cl}(x \leq$ $0.3)$ exhibits one dominant band peaked at $4.5 \mathrm{eV}$ [6-8]. Fig. 1 shows the emission spectrum of $\mathrm{Rb}_{0.82} \mathrm{Cs}_{0.18} \mathrm{Cl}$ crystal measured at 295 and $8 \mathrm{~K}$ under excitation with $2870 \mathrm{eV}$ photons. Apparently the luminescence band with the maximum at $4.5 \mathrm{eV}$ observed in the crystal is the impurity CVL of the mixed rubidium-caesium chloride. Previous systematic studies have shown that the appearance of the luminescence spectrum in the materials with the impurity CVL is controlled by the structure of the $\left[\mathrm{CsCl}_{n}\right]$ cluster which is responsible for CVL: a single band is detected in the case of octahedral surrounding of Cs $(n=6)$ while a second high energy band at 5.2 $\mathrm{eV}$ arises if there are $8 \mathrm{Cl}^{-}$anions in the first coordination sphere [6]. As a matter of fact one can notice a 
trace of this weak emission band at the high-energy side of the main $4.5 \mathrm{eV}$ band. Reducing the temperature of the sample results in the narrowing of the emission band and an increase in the emission efficiency. Altogether the results of present luminescence characterization are in good compliance with the previous studies [6-8]. This indicates that impurity CVL of mixed rubidium-caesium chloride can be easily identified at the given excitation conditions and this forms the foundation for the following measurements of the excitation spectra.

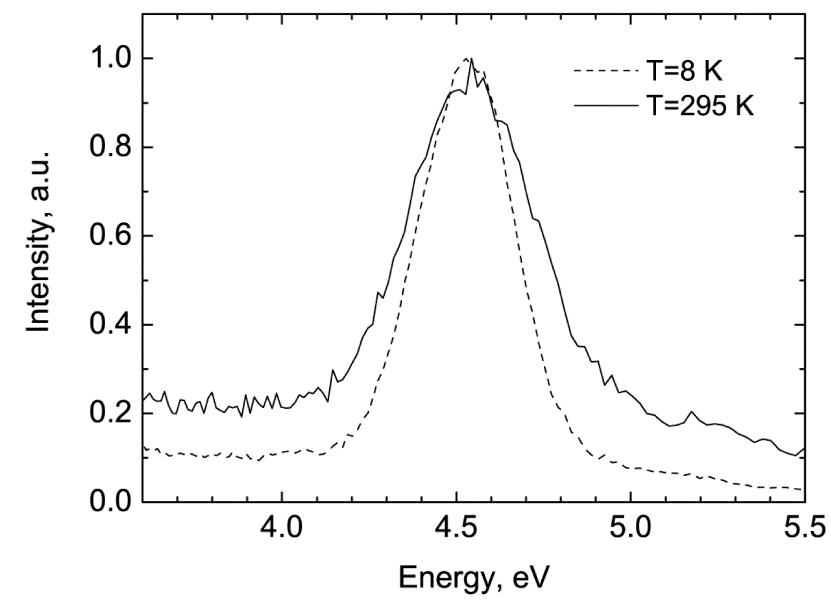

Fig. 1. Impurity CVL spectrum of $\mathrm{Rb}_{0.82} \mathrm{Cs}_{0.18} \mathrm{Cl}$ crystal measured under excitation with $2870 \mathrm{eV}$ photons.

Fig. 2 shows the excitation spectra for the impurity $\mathrm{CVL}$ band of $\mathrm{Rb}_{0.82} \mathrm{Cs}_{0.18} \mathrm{Cl}$ crystal recorded in the region of K-absorption edge of chlorine. For the sake of convenience of comparison the baseline correction was done by the intensity of the luminescence signal just before the edge (so-called white signal) and the luminescence yield spectra presented here are normalised at the first maxima. The figure also displays the K-absorption spectrum of $\mathrm{Cl}$ in $\mathrm{RbCl}[10]$. It is immediately seen that the luminescence excitation and XANES absorption spectra exhibits virtually one-to-one correspondence. Several interesting features are becoming apparent. First, the XEOL yield spectrum can accurately reproduce the XANES data obtained with the conventional detection technique. Second, there are no noticeable changes in the spectra with the temperature. Finally, what is most important, this observation provides valuable structural information about $\mathrm{Rb}_{0.82} \mathrm{Cs}_{0.18} \mathrm{Cl}$ crystal. Indeed, the near edge absorption spectrum is the characteristic of the peculiar local surrounding of the absorbing atom [1-4]. Therefore, the resemblance of the XANES of $\mathrm{RbCl}$ and XEOL yield spectrum of $\mathrm{Rb}_{0.82} \mathrm{Cs}_{0.18} \mathrm{Cl}$ crystal reveals that absorbing chlorine atoms in the lightly-doped $\mathrm{Rb}_{1-x} \mathrm{Cs}_{x} \mathrm{Cl}$ crystal are localised in the same regular positions, as they are in pure rubidium chlorine. Given the fact that emission process occurs within the $\left[\mathrm{CsCl}_{n}\right]$ cluster $[6,7]$ one can argue that Cs atoms also occupy regular anion places in the $\mathrm{NaCl}$-type crystal lattice which is inherited by mixed $\mathrm{Rb}_{0.82} \mathrm{Cs}_{0.18} \mathrm{Cl}$ crystal. This finding provides evidence in support of previous interpretation of the impurity CVL based on the cluster model $[6,7]$.

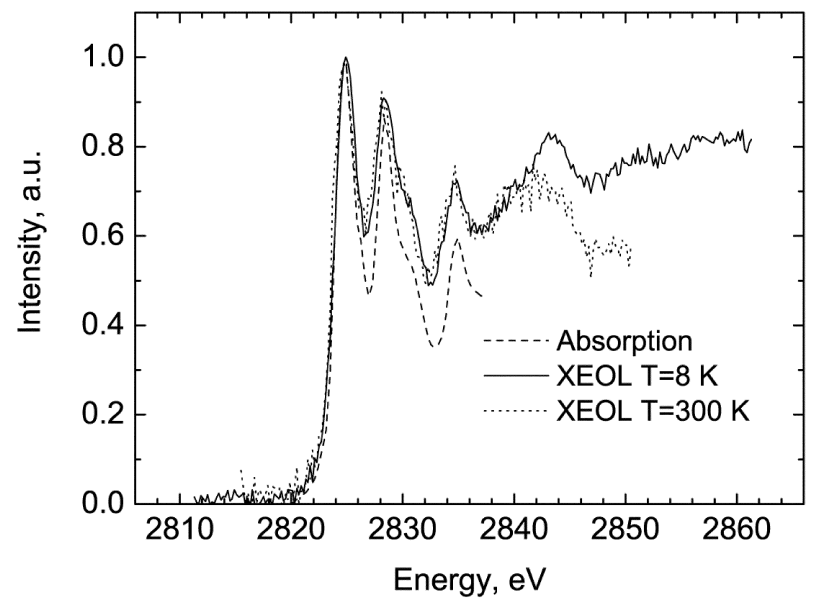

Fig. 2. Excitation spectra of the impurity CVL of $\mathrm{Rb}_{0.82} \mathrm{Cs}_{0.18} \mathrm{Cl}$ crystal and absorption spectrum of $\mathrm{RbCl}$ [10] in the region of $\mathrm{Cl} \mathrm{K}$-edge.

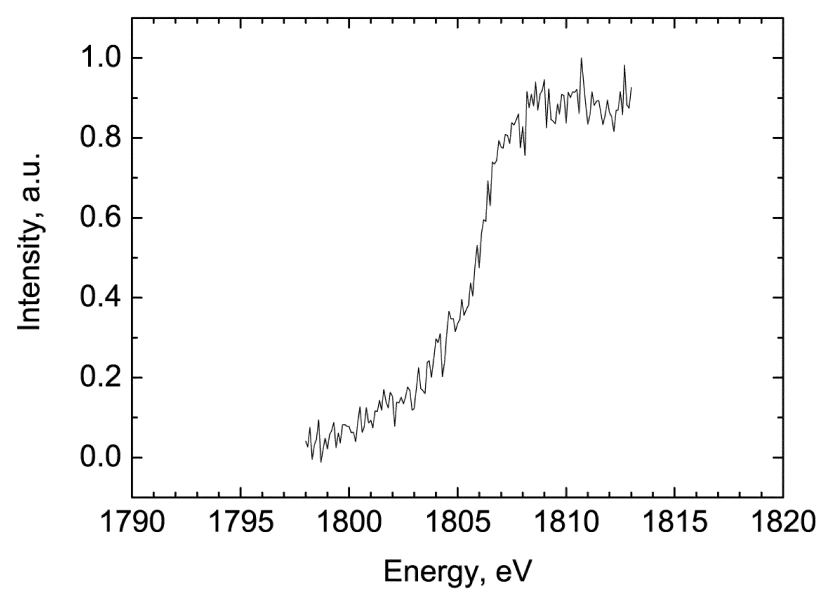

Fig. 3. Excitation spectra of the impurity CVL of $\mathrm{Rb}_{0.82} \mathrm{Cs}_{0.18} \mathrm{Cl}$ crystal at $\mathrm{Rb} \mathrm{L}_{3}$-edge.

Apparently it would be ideal to obtain the same evidence of the local surrounding by making XEOL measurements in the vicinity of the cation absorption edges of the crystal. Such an experiment has been done indeed and Fig. 3 shows the excitation spectrum of the impurity CVL recorded at $\mathrm{L}_{3}$-absorption edge of rubidium. Unfortunately, the photon flux of the primary X-ray monochromator in this spectral region is low and therefore the recorded signal is very week. Furthermore, the clarity of the structure of L-absorption edges of heavy atoms is inferior comparing with that at the K-edge. Altogether these bring about very noisy luminescence yield spectrum with the smeared indication of the positive threshold at $1804 \mathrm{eV}$ that is identified as $\mathrm{Rb} \mathrm{L}_{3}$-absorption edge. 


\section{CONCLUSIONS}

Summing up it can be concluded that the results obtained in this study allowed to assertain the structure of the emitting centre responsible for impurity CVL in the mixed $\mathrm{Rb}_{0.82} \mathrm{Cs}_{0.18} \mathrm{Cl}$ crystals. In this case it is the $\left[\mathrm{CsCl}_{6}\right]$ octahedral cluster embedded in the regular f.c.c. lattice of $\mathrm{RbCl}$. This finding gives a good example of the applicability of XEOL technique for structural studies of the luminescence centres. Further investigations of the samples with varied concentration are in progress that will help to clarify the scope of applicability of the technique.

\section{ACKNOWLEDGEMENTS}

The support obtained from the SRS Daresbury Laboratory through proposal 42231 is gratefully acknowledged.
[1] Boon K. Teo, EXAFS: Basic principles and data analysis, (Berlin, New York, Springer-Verlag, 1986).

[2] A. Bianconi, D. Jackson and K. Monahan, Phys. Rev. B 17, 2021 (1978).

[3] Y. F. Hu, K. H. Tan, P. S. Kim, P. Zhang, S. J. Naftel, T. Sham, I. Coulthard, B. W. Yates, Rev. Sci. Instr. 73, 1379 (2002).

[4] S. Emura, T. Moriga, J. Takizawa, M. Nomura, K. R. Bauchspiess, T. Murata, K. Haradak, H. Maeda, Phys. Rev. B 47, 6918 (1993).

[5] L. Soderholm, J. K. Liu, M. R. Antonio, F. W. Lytle, J. Chem. Phys. 109, 6745 (1998).
[6] A. S. Voloshinovskii, M. S. Mikhailik, V. B. Mikhailik, E. N. Mel'chakov, P. A. Rodnyi, C. W. E. van Eijk, G. Zimmerer, J. Lumin. 79, 107 (1998).

[7] V. B. Mikhailik, A. S. Voloshinovskii, G. Zimmerer, J. Alloys Comp. 286, 128 (1999).

[8] V. B. Mikhailik, A. S. Voloshinovskii, V. Kisand, S. Vielhauer, Phys. Status Solidi b 212, 367 (1999).

[9] F. Quinn, N. Poolton, A. Malins, E. Pantos, C. Andersen, P. Denby, V. Dhanak, G. Miller, J. Synchrotron Radiat. 10, 46 (2003).

[10] C. Sugiura, J. Chem. Phys. 58, 3527 (1973).

\title{
ДОСЛІДЖЕННЯ ДОМІШКОВОЇ ОСТОВНО-ВАЛЕНТНОЇ ЛЮМІНЕСЦЕНЦІЇ ЗМІШАНОГО ХЛОРИДУ РУБІДІЮ Й ЦЕЗІЮ ПРИ ЗБУДЖЕННІ В ДІЛЯНЦІ РЕНТГЕНІВСЬКОГО ПОГЛИНАННЯ
}

\author{
В. Б. Михайлик \\ Фізичний факулътет, Оксфордсъкий університет, Оксфорд, Великобританія
}

\begin{abstract}
Домішкову остовно-валентну люмінесценцію (ОВЛ) змішаних кристалів Rb0.82Cs0.18Cl досліджено при збудженні в околі K-краю поглинання $\mathrm{Cl}$ та L-краю поглинання Rb з використанням люмінесцентної спектроскопії як методу детектування. Показано, що в ділянці К-краю поглинання Сl спектри збудження домішкової ОВЛ є ідентичними до спектрів рентгенівського поглинання RbCl. Установлено, що дослідження спектрів збудження домішкової ОВЛ в ділянці країв рентґенівського поглинання може дати інформацію про структуру оточення центра випромінювання.
\end{abstract}

